\title{
Measuring the Impact of Employee Learning At Work: A Review of the Practices of Two Companies in Ghana
}

\section{Coleman $\mathrm{CA}^{1,2}$}

${ }^{1}$ Department of Organization and Human Resource Management Legon, University of Ghana Business School, Ghana 2IMANI Africa Centre For Policy Education, Accra, Ghana

\begin{abstract}
Organizational performance requires significant investment in employee learning. While studies on employee learning have been on the ascendancy within the domain of human resources management and development theory, there is a relative paucity of research on how employers measure the impact of employee learning programmes in Ghana. Using data from two organizations in Ghana, this paper considers the constraints and enablers that organizations face and suggests a framework to measure the impact of employee learning programmes. The findings conclude that three key factors are required in order to assess the impact of employee learning programmes within organizations namely organizational culture, theory of change and support systems.
\end{abstract}

Keywords: Organizational culture; Employee learning; Theory of change

\section{Introduction}

Employee learning refers to all the policies, programs, processes and activities that go into identifying, nurturing, developing and appropriately rewarding the talents and capabilities of an individual. It is a process to facilitate personal and professional development, to reinforce self-belief in a person to realize his/her full potential in a sustainable manner [1]. Employee learning is an enabler for changing behavior and skills [2]. Investing in employee learning is a source of motivation for staff [3]. Employees pay a high value on learning if it will lead to a favorable outcome [4]. Many organizations invest in executive training programmes for their employees as a means to improve organizational performance [5]. Managers play a key role in facilitating employee learning and development [6]. Employers are focusing on competence-based management education to drive productivity [7]. Irrespective of the positive intentions behind employee learning and development, very often, the measurement of the impact of employee learning programmes in human resources management is often a challenging process. $[8,9]$. Whereas investment in data infrastructure can normally be defined as cost saving leading to improved data driven decision making, the outcomes of employee learning programmes and their impact on business is often difficult to assess [10]. This is due to the fact that the immediate learning objectives and outcomes to be realized are often not expressed in quantitative terms. It identifies a number of factors that make most HR and training staff shy away from doing ROI assessments on employee learning programmes including the absence of pressure from senior management to conduct a post learning knowledge transfer and its impact on business performance.

Employees in most organizations are adults and any strategy for employee learning must consider the conceptual framework that under pins adult learning Linderman [11], Based on his experience as both an adult learner and a teacher of adults, proposed that adults were not just grown-up children, that they learned best when they were actively involved in determining what, how, and when they learned. Argyris and Kaplan [12] have concluded that implementing new knowledge gained after an employee learning programmes can be enhanced by activity based costing.

According to them, there are six main assumptions underpinning adult learning:
1. Adults have a need to know why they should learn something.

2. Adults have a deep need to be self-directing.

3. Adults have a greater volume and different quality of experience than youth.

4. Adults become ready to learn when they experience in their life situation a need to know or be able to do in order to perform more effectively and satisfyingly.

5. Adults enter into a learning experience with a task-centered or problem/life centered orientation to learning or in simple terms real life experiences.

6. Adults are motivated to learn by both extrinsic and intrinsic motivators.

Mayo [13] argues that in the field of training, organizational change and HR initiatives, employers are most likely to be aiming for non-financial benefits in the first place than for a targeted bottom line gain. Alder [8] has stressed the need for evaluating the impact of employee learning vis-a-vis the added benefit to company performance. Kirkpatrick [14] defined four levels for evaluating a training programme- the first was the experience itself, followed by evidence of real learning. The third was application of the learning to the workplace and finally the effect on the bottom line. He added ROI as level 5. Mayo [13] has suggested a "level 0" which is fundamental, and that is the setting of the objectives of the programme. In this research we will argue that three key enablers are required before a rigorous measurement of the impact of employee learning can be effectively conducted. These are organizational culture, theory of change (TOC), and support systems. Luiten et al. [15] have argued that measuring

*Corresponding author: Coleman CA, Department of Organization and Human Resource Management, University of Ghana Business School, P.O. Box LG 78, Legon, Accra, Ghana, Tel: +233501581492; E-mail: caselycoleman@yahoo.co.uk

Recieved November 14, 2018; Accepted November 20, 2018; Published November 28, 2018

Citation: Coleman CA (2018) Measuring the Impact of Employee Learning At Work: A Review of the Practices of Two Companies in Ghana. J Entrepren Organiz Manag 7: 251. doi: 10.4172/2169-026X.1000251

Copyright: (c 2018 Coleman CA. This is an open-access article distributed under the terms of the Creative Commons Attribution License, which permits unrestricted use, distribution, and reproduction in any medium, provided the original author and source are credited. 
employee learning is critical to assess learning transfer, retention and application of knowledge. Lumsden and Sheron [16] assert that employees as adults bring life experiences into any learning space and this must be factored in assessing knowledge transfer before and after a learning intervention. Wholey [17] avers that managers need to ensure that the views of all internal and external constituencies are considered when post learning evaluation criteria are developed. In order to measure the impact of any employee learning programme, it is important to have employee group support systems to improve the learning environment [18].

\section{Purpose of study}

Competitive advantage in business requires significant investment in employee learning [19]. While studies on employee learning have been on the ascendency within the domain of human resources management and development theory, there is a relative paucity of research on how employers measure the impact of employee learning programmes in Ghana. Using data from two organizations in Ghana, this paper considers enablers and constraints that organizations face on how they measure the impact of employee learning programmes. This article examines data from two companies in Ghana and how they assess the impact of employee learning programmes. Company one operates in the international development sector and company two operate in the logistics sector. For purposes of the research we will identify company one " $\mathrm{A}$ " and company two " $\mathrm{B}$ ". Based on the study we shall propose a framework that can be applied to improve $\mathrm{HR}$ processes to assess the impact of employee learning programmes to organizational performance.

\section{Resume of Company A}

Established in 2000, the organization is one of the leading haulage, logistics and freight forwarding companies in Ghana with a delivery model with a focus on client's satisfaction. The company has established itself as one of the most reliable players in the freight forwarding sector and is poised to grow with the potential to become the leading freight forwarding and logistics company in Ghana and within the sub region. The company currently employs over 260 full time staff with an average turnover of $\$ 5 \mathrm{~m}$ and is currently embarking on expanding its business by building a new terminal, acquiring new clients and also sustaining current competitiveness in a rapidly changing business landscape.

\section{Resume of Company B}

Established in 2005, the organization is an international nongovernmental organization and very highly respected in Ghana. Its core business includes implementing programmes in livelihood, civil society capacity building, advocacy and climate change. It raises funds from donors and has over 275 employees including 5 expatriate staff. It has recently won a major grant to implement an educational transformation project which will result in further expansion of the scope of operations across the country. The Executive Director has recently hired an HR Manager with expectations of an immediate turnaround of HR services and processes.

\section{Methodology}

The study was empirical in nature and combined an inductive and deductive approach as a basis for reviewing the employee learning practices in the two organizations. The deductive approach involved reviewing literature and documents available at the two organizations, whereas the inductive approach was based on empirical data obtained from interviews and questionnaire administered to the respondents.
The population of the study included logistics sector and international nongovernmental (INGO) sector employees working in junior, middle and executive level. Both organizations were based in Accra and both had staffing levels in excess of 250. Participants had worked in their organization an average of 5.37 years $(S D=6.07)$ with total work experience averaging 7.84 years $(\mathrm{SD}=6.47)$. Their ages ranged from 25 to $48(\mathrm{M}=31.07, \mathrm{SD}=6.77)$. About $39 \%$ were male, $51 \%$ were female. $65 \%$ of respondents in Company $\mathrm{A}$ had at least a first degree, while $55 \%$ of respondents in Company B had an undergraduate or a more advanced degree. In order to conduct the survey 50 questionnaires were distributed out of which 44 questionnaires were returned showing $88 \%$ response rate. The questionnaires were rated on a five point Likert scale where 1 refers to strongly disagree and 5 refer to strongly agree. The sample size of 44 is considered to be sufficient according to central limit theorem.

A questionnaire was administered to 44 individuals, these ranged from CEOs, line managers, HR Managers and junior staff. Specific numbers are provided below (Table 1).

Follow up interviews were done with the respondents to ensure the reliability and validity of the responses. Interviews and a review of relevant documentation were used in the analysis as this is critical to determine an accurate first hand assessment of their employee learning practices. He argues that qualitative research is applicable for the purposes of description, interpretation, verification and evaluation. This is very relevant for our study since it helps to review the various approaches to employee learning practices and how learning impact is measured in the two organizations.

\section{Questionnaire}

Using a likert scale from 1-5, 1): Strongly disagreed, 2): Disagreed, 3): Neither agrees nor disagrees, 4): Agree,

5): Strongly agree, the questionnaire covered the following areas:

1. Values: In my organization senior managers value employee learning and development.

2. HR Strategy: In my organization there is a written HR strategy that articulates the value of employee learning.

3. Transparency: In my organization I know the amount of money that is applied for employee learning and development.

4. Tools for Evaluation: In my organization there are tools for assessing the impact of employee learning.

5. Supervision: My supervisor provides me with coaching when I return from training.

6. Evidence of Impact: I can show the line of sight between the effect of my training and the performance of the company.

7. Culture of sharing learning: In my company I have the opportunity to present my experiences from the learning program.

\begin{tabular}{|c|c|c|}
\hline NO & Position & Quantity \\
\hline 1 & CEO & 2 \\
\hline 2 & Line managers & 20 \\
\hline 3 & HR Managers & 2 \\
\hline 4 & Junior Staff & 20 \\
\hline
\end{tabular}

Table 1: A questionnaire was administered to 44 individuals, these ranged from CEOs, line managers, HR, Managers and junior staff. 
8. Pre learning objectives: My supervisor engages with me to set learning objectives before I attend learning programme.

9. Defining post learning standards: My line manager agrees post learning standards with me before I begin my learning program.

10. Data: In my organization we have HRIS to manage data from all employee learning programmes.

11. Selection Process: Selection for employee learning and development initiatives are based on a transparent process (Table 2).

\section{Results and Analysis}

This section discusses the findings under three main headings; organizational culture, strategy and systems and proposes a framework to facilitate measurement of employee learning programmes.

\section{Organizational culture}

Organizational culture refers to the pattern of shared values, beliefs, and assumptions considered being the appropriate way to think and act within an organization [20]. They constitute the beliefs and values, and how they are manifested [21].

In both companies very significantly high numbers of the respondents $65 \%$ and $75 \%$, respectively agreed or strongly agreed that senior managers value employee learning and development. However only $10 \%$ and $20 \%$ of respondents in both companies agreed or strongly agreed that there is access to information on how much the organization invests in employee learning. This depicts a culture of lack of transparency in access to information on employee learning and development.

In both companies there were very low scores on the extent to which employees have the opportunity to present their experiences upon return from the learning program. $90 \%$ and $85 \%$ respectively responded neutral, disagree or strongly disagreed that they have opportunities to share their experiences after a learning programme. The implication is that at three levels i.e., sharing the experience itself, showing evidence of real learning and application of the learning to the workplace was lacking. Under culture of sharing learning, only $10-15 \%$ of respondents agreed or strongly agreed that they have the opportunity to present their experiences from the employee learning program.

\section{Strategy}

On HR strategy, in organizations, only $20 \%$ and $35 \%$ agreed or strongly agreed to the question there exists a written HR strategy that articulates the value of employee learning. An HR strategy provides a framework to define and measure a clear theory of change on key HR outcomes such as building leadership pipeline, holding staff accountable through a coherent performance management system, a key aspect of which is employee learning to support business performance. Without an HR strategy that frames the strategic outcomes for employee learning, it will be difficult to measure knowledge transfer and learning impact.

\section{Systems}

$35 \%$ of respondents of Company A and $45 \%$ of respondents of Company B agreed or strongly agreed that in their organization there are tools for assessing the impact of employee learning. This means in both companies more than half of their staff were either neutral or disagree that there are tools for assessing post learning impact. In any $\mathrm{HR}$ intervention, learning activities need to be measured and evaluated to ensure their ongoing worth [22]. Assessment is important as it becomes an enabler for continuous process and product improvements. The data suggests that without a means to measure the impact of the employee learning program, HR Managers and line managers will struggle to sustain the support for their CEOS for more investment in employee learning programmes. The CEO of Company A said "I tend to support employee learning initiatives when they demonstrate that they are consistently converting learning into improved organizational performance".

On supervision, only 20 to $35 \%$ of staff in both companies agree or strongly agree that their supervisor provides coaching after training. In regards to showing evidence of Impact of employee learning, only $10-15 \%$ of respondents in both companies agreed or strongly agreed that they can show the line of sight between the effect of their training and the performance of the company. The methodology for identifying employees for learning programmes can often trigger tension within the workplace. In our research, on this particular factor, the data was mixed. In Company A while $20 \%$ agree or strongly agree that the selection process for employee learning programmes was transparent, in Company B it was $45 \%$ who agreed or strongly agreed. When we asked staff of Company B for evidence, they mentioned that the existence of a Staff Educational assistance committee in their organization which meets yearly to consider commendations from Line Managers for employee learning programme request. While this may account for the relatively higher positive ratings, the fact that over half of the respondents did not agree or strongly agree shows that the degree of transparency in the approval process is still an issue.

\section{Defining theory of change for employee learning}

With respect to pre learning objectives only $20-30 \%$ of respondents

\begin{tabular}{|c|c|c|}
\hline Question & \multicolumn{1}{|c|}{ Co A } \\
\hline 1 & $75 \%$ responded 4 or 5 on the scale & $65 \%$ responded 4 or 5 on the scale \\
\hline 2 & $20 \%$ responded 4 or 5 on the scale & $35 \%$ responded 4 or 5 o the scale \\
\hline 3 & $10 \%$ responded 4 or 5 on the scale & $20 \%$ responded 4 or 5 on the scale \\
\hline 4 & $35 \%$ responded 4 or 5 on the scale & $45 \%$ responded 4 or 5 on the scale \\
\hline 5 & $20 \%$ responded 4 or 5 on the scale & $35 \%$ responded 4 or 5 o the scale \\
\hline 6 & $30 \%$ responded 4 or 5 on the scale & $15 \%$ responded 4 or 5 on the scale \\
\hline 8 & $10 \%$ responded 4 or 5 on the scale 4 or 5 on the scale \\
\hline 9 & $20 \%$ responded 4 or 5 on the scale & $30 \%$ responded 4 or 5 on the scale \\
\hline 10 & $5 \%$ responded 4 or 5 on the scale & $10 \%$ responded 4 or 5 on the scale \\
\hline 11 & $40 \%$ responded 4 or 5 on the scale & $48 \%$ responded 4 or 5 on the scale \\
\hline & $20 \%$ responded 4 or 5 on the scale & $45 \%$ responded 4 or 5 on the scale \\
\hline
\end{tabular}

Table 2: Analysis of questionnaire. 
Citation: Coleman CA (2018) Measuring the Impact of Employee Learning At Work: A Review of the Practices of Two Companies in Ghana. J Entrepren Organiz Manag 7: 251. doi: 10.4172/2169-026X.1000251

Page 4 of 6

of both organizations agreed or strongly agreed that their supervisor engages with them to set pre learning objectives before they attend a learning programme. On the other hand on defining post learning standards - Only $5-10 \%$ of respondents agree or strongly agree that their line manager agrees post learning standards with them before they begin their learning program in order to assess learning impact and knowledge transfer and application after the learning programme (Figure 1).

\section{A Framework for Measuring Employee Learning Programmes}

HR practices such as employee learning programmes must be conceptualized as a means to strengthen the intellectual capital of the organization and must be seen as a source of organizational agility. However employee learning programmes must demonstrate how they enable the attainment of company strategic intent and priorities. Based on this research three key enablers are proposed as critical to improving organizational capability to measure the impact on employee learning programmes. Organizational culture to define the right values and principles to serve as the foundation of employee learning, Theory of change(TOC) define a "future state, assess the "status quo", measure progress towards learning transfer and Supporting systems to reinforce the first 2 enablers.

\section{Organizational culture and values driven policy and principles}

A well-developed organizational culture of promoting learning in which management and staff are thoroughly socialized promotes stronger organizational commitment, higher morale and more efficient performance. It is important to establish a favorable work unit climate for effective employee learning through an organizational culture that has institutionalized learning through building the right values that drives the policies, systems, rituals and artifacts and reinforced by senior leaders who invest in employee learning and recognize and rewards employees whose post learning skills positively impacts the business of the organization. Another related factor which is key to reinforce a favorable climate of learning is to encourage sharing of employee learning experiences on a continuous basis [23]. Employees learn best when they can bring their experiences to bear on the learning process cell [24].
Employee learning programmes must be established on clearly defined policy with foundational principles that provides broad guidelines on the "spirit" and "letter" for managing employee learning. An employee learning policy must have some of the following eight principles:

- Recognition of the contribution of all employees and an acknowledgment and respect for diverse approaches and beliefs.

- Recognition that employees are the most important resource in the organization and it is through employees that other resources and strategies can be fully and efficiently utilized and implemented.

- Recognition that investing in employees is the most appropriate way that current performance, job security and future career development can be assured.

- A statement that proven performance, fairness, due process and equity shall constitute the foundation for assessing and recommending employee learning programmes.

- An acknowledgement that every employee has a right of access to support subject to availability of available resources to enable them to develop to realize their full potential, fulfill their responsibilities and perform to the best of their ability.

- A proviso that each employee must take appropriate responsibility for their own learning if a win-win participatory process of employee learning and development is to be achieved.

- A clear requirement that employee learning is a primary accountability of line managers and must be part of the minimum performance indicators for line managers.

- A proviso that budgetary allocations for employee learning shall be consistent with the firm's corporate governance structures which requires accountability for the use of resources from key decision makers, and that the provision of opportunities will be based on the appropriate level and degree of need that will reflect the firms established strategic intent and priorities.

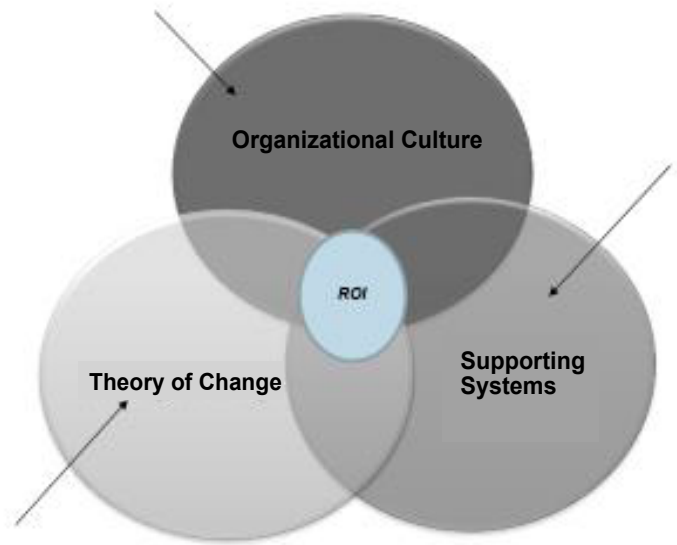

Figure 1: Framework for measuring $\mathrm{ROI}$ on employee learning programme. 


\section{Theory of change}

A theory of change defines the future end state of any change intervention. When applied to employee learning, it means a definition of clear outcomes with indicators of what success looks like after the learning is completed and the skills transferred and applied to the business. Employee learning process is a change intervention to achieve certain clear outcomes to improve business performance [25].

A theory of change for employee learning programmes must define "future state" outcomes that:

- Strengthens a commitment to the organization's vision, mission, values, business strategy and working approach.

- Increases the effectiveness of the organization to achieve its objectives through improving the performance of individuals as they perform their tasks.

- Leads to qualitatively and quantitatively high standards, improved business processes and outcomes.

- Identifies and develops competencies appropriate for managing actual or anticipated skilled labor shortages within the framework of the organization's business strategy.

- Encourages an enabling environment of due process, fairness, transparency, innovativeness, personal development and consistent learning.

- In line with a fundamental principle to provide opportunity for all employees to nurture and realize their full development potential in the organization.

The development of a theory of change for employee learning must be preceded by a definition of the "status quo" of employee learning deficit, in order to satisfy the basic business logic of "value-for-money". The definition of the "status quo" must diagnose whether the proposed employee learning programme is:

- A process or activity to acquire completely new perspectives, skills and knowledge?

- A process or activity to upgrade current levels of perspectives, skills and knowledge?

- A process or activity to revise perspectives, skills and knowledge?

This process will help to determine the right standards of knowledge impact and teach transfer to be assessed after the learning programme. This will then become the basis for determining return on investment of the learning programme to improved organizational performance.

\section{Supporting systems}

In order to measure the impact of any employee learning programme, it is important to have the necessary organizational supporting systems. Firstly supervision provides an opportunity for employee to engage with their supervising manager in the learning process that encourages respect and recognition of diverse individual working styles, joint problem identification and management, and the provision of required resources and support which actively promotes continuous and consistent learning and development to reinforce skills gained after the completion of an employee learning programme.

Secondly an efficient human resources information system infrastructure is also a key supporting system for assessing the impact and Transfer after an employee learning program. Employee learning programmes must be based on the outcome of a performance management process cycle and in addition reinforced by periodic recommendations by heads of departments in consultation with HR and approved by senior management.

Thirdly employee learning programmes must aim to address skilled labor shortage in the short or long term. Skilled labor shortage is defined as actual or anticipated inability to access and deploy the required mix of competencies, qualitatively in terms of technical skills, knowledge and attitudes, and quantitatively in terms of staffing numbers, levels and requirements. The value of employee learning programs to senior managers will be enhanced if HR can submit monthly, quarterly and yearly reports that analyses trends that shows the extent to which employee learning programmes address skilled labor shortages in the short, medium and long term.

Fourthly, it is crucial to have an effective new employee socialization process at entry level where new employees are provided with thorough induction on the culture, principles, theory of change and supporting systems that underpin their learning and development during the period of their employment.

Finally, there is need for an HR strategy that will define the high level strategic priorities of the organization in terms of how it will attract, develop and retain highly qualified and agile employees. The HR strategy will provide conceptual clarity on key business outcomes that HR will work with line managers to deliver including employee teaching which a key aspect of talent management [26]

Assessing employee learning programme is a very core aspect of strategic HR. Diagnosing employee learning deficits requires a coherent theory of change that is anchored on a strong organizational culture and supported with the right supporting systems [27,28]. An efficient and integrated approach to assessing the impact of employee learning staff capacity building can only be realized when all the above factors are in place $[29,30]$. It requires consistency at all levels where line managers are accountable one-to-one supervision, providing coaching and working as team with facilitative support from HR [31].

\section{Conclusion}

Employee learning refers to all the policies, programs, processes and activities that go into identifying, nurturing, developing and appropriately rewarding the talents and capabilities of an individual. It is a process to facilitate personal and professional development, to reinforce self-belief in a person to realize his/her full potential in a sustainable manner. Measuring the impact of employee learning programmes requires an effective learning resources strategy anchored on the right organizational culture that provides a framework to determine the types of learning resources will add value to organizational performance in line with corporate strategy. It entails a thorough diagnosis of the type of support systems that will create a favorable climate learning to take place in order to evaluate the impact of knowledge transfer and application. Employee learning interventions must deliver value to organizational stakeholders namely employees, line managers, clients and shareholders.

Measuring the ROI on employee learning is maximized when it is targeted at real business challenges, from design, execution, monitoring and evaluation of business processes and outcomes. Measurement of employee learning outcomes helps to ensure a line of sight between the business needs of the organization and individual capabilities and facilitates the creation of value for business performance. Employee 
Citation: Coleman CA (2018) Measuring the Impact of Employee Learning At Work: A Review of the Practices of Two Companies in Ghana. J Entrepren Organiz Manag 7: 251. doi: 10.4172/2169-026X.1000251

Page 6 of 6

learning creates value by helping individuals and organizations anticipate and respond to change. By responding to the three questions i.e., is it a process to acquire new skills, refresh new skills or upgrade existing skills, the L\&D intervention helps to respond to the pace of change and required impact on organizational performance. The research from the two companies confirmed weakness in getting the right organizational culture, inadequate articulation of a coherent theory of change of employee learning and ineffective supporting systems to assess the impact of employee learning programmes. The findings of this study is restricted to only two organizations and therefore cannot be generalized across board, however it provides a basis for further studies on employee learning and its return on investment on organizational performance.

\section{References}

1. Coleman CA (2006) The Millennium Challenge Account and Human Resources Development of Ghana in Africa Update. Central University of Connecticut.

2. Mangham I (1948) Interactions and interventions in Organizations. New York, Wiley.

3. Benkhoff B (1996) Motivating Employees to Work Harder. J Hum Resour Manage.

4. Vroom VH (1982) Work and Motivation. Wiley.

5. Stuller J (1993) Practical Matters: Executive Training Programs. Across the Board 30: 36-40.

6. Weaver RG, Farrell JD (1997) Managers As Facilitators. San Francisco: BerretKoehler.

7. Albanese R (1989) Competence-based management education. J Manag Dev 8: $66-76$

8. Alder NJ (1992) The bottom line. Training Tomorrow, pp: 33-34.

9. Burt RS, Ronchi D (2007) Teaching Executives to see social capital: results from a field experiment. Soc Sci Res 36: 1156-1183.

10. Kearns P, Currant N (2005) Evaluating the ROI From Learning: How to Develop Value Based Training. CIPD 37: 319-319.

11. Linderman EC (1926) The Meaning of Adult Education: A Classic North American Statement on Adult Education. New York: New Republic.

12. Argyris C, Kaplan RS (1994) Implementing new knowledge: The case of activity-based costing. Accounting Horizons 8: 83-105.
13. Mayo A (2008) Getting A Return on People Programmes. Finance and Management.

14. Kirkpatrick DL (1998) Another Look at Evaluating Training Programmes: Fifty Articles From 'Training \& Development' and 'Technical Training' Magazines Cover the Essentials of Evaluation and Return-on-Investment. ASTD.

15. Luiten J, Ames W, Ackerman GA (1980) A Meta-Analysis of the Effects of Advance Organizers on Learning and Retention. Am Educ Res J 17: 211-218.

16. Lumsden DB, Sheron RH (1975) Experimental Studies in Adult Learning and Memory. New York: Wiley.

17. Wholey JS (1991) Using evaluation to improve program performance. The Bureaucrat 20: 55-59.

18. Briggs RO, Ramesh V, Romano NC Jr., Latimer J (1994-1995) The exemplar project: Using group support systems to improve the learning environment. J Educ Tech Syst 23: 277-291.

19. Boudreau JW, Ramstad PM (1997) Measuring intellectual capital: Learning from financial history. Hum Resour Manage 36: 343-356.

20. Bedingham K (1999) The Measurement of Organizational Culture. J Hum Resour Manage.

21. Schein EH (1983) The Role of the Founder in Creating of Organizational Cultures. Organ Dyn 12: 13-28.

22. Raelin JA (1997) A model of work-based learning. Organ Sci 8: 563-578.

23. Sutton D (1989) Further thoughts on action learning. Journal of European Industrial Training 13: 32-35.

24. Cell E (1984) Learning to Learn from Experience. Albany: State University of New York

25. Olian JD, Durham CC, Kristof AL, Brown KG, Pierce RM, et al. (1998) Designing management training and development for competitive advantage: Lessons from the best. Human Resource Planning 21: 20-31.

26. Berger L, Berger D (2004) The Talent Management Handbook. Mcgraw Hill.

27. Kearns $P$ (2000) Maximizing the ROI from training - measure the value added by employee development. FT-Prentice Hall.

28. Mayo A (2004) One Stop Guide to HR Return on Investment. Personnel Today

29. Ulf Johanson (1997) Return on Investment in Training and Performance Improvement Programmes $2^{\text {nd }}(E d n)$. Houston, TX:Gulf Publishing Company.

30. Schein EH (1965) Organizational psychology. Oxford, England: Prentice-Hall.

31. Van de Ven AH, Poole MS (1995) Explaining development and change in organizations. Acad Manage Rev 20: 510-540. 